UJMR, Volume 5 Number 2, December, 2020, pp 131 - 137 ISSN: 2616 - 0668

Received: $21^{\text {st }}$ November-, 2020 Accepted: $20^{\text {th }}$ December, 2020

https://doi.org/10.47430/ujmr.2052.018

\title{
Potentials of Acremonium butyri fungus in pre-treatment and hydrolysis using Rice husk substrate for biofuel production: A short communication
}

\author{
${ }^{1}$ Sanusi, A., ${ }^{2}$ Farouq, A. A., ${ }^{2}$ Ibrahim, A. D., ${ }^{1}$ Shamsudeen, M. M., ${ }^{3}$ Usman, M. H. and \\ ${ }^{4}$ Bello, A. Y \\ ${ }^{1}$ Department of Microbiology, Kebbi State University of Science and Technology Aliero. \\ ${ }^{2}$ Department of Microbiology, Usmanu Danfodiyo University, Sokoto. \\ ${ }^{3}$ Department of Microbiology, Sokoto State University. \\ ${ }^{4}$ Depatment of Basic Science and General Studies, Federal Collage of Forestry Mechanization Afaka, \\ Kaduna, Nigeria \\ ${ }^{*}$ Corresponding Author: sanusiabubakar234@gmail.com
}

\begin{abstract}
There is increasing interest in the area of biofuel production due to fear of fossil fuel extinction as a result of over exploitation and crises. During biofuel production, substrate needs to undergo pre-treatment and hydrolysis where acids and alkali are mostly used. In this study, Acremonium butyri was used for both pre-treatment and hydrolysis. Structural compositions of the rice husk were determined. Extractives, hemicellulose and Lignin content was determined via extraction using Soxhlet extractor while cellulose was determined as the difference from the extractives, hemicelluloses and lignin. Acremonium butyri was isolated from dried roots of Piliostigma reticulatum (Kalgo) by keeping the roots in a clean plastic for a period of 7 days on moist environment after which fungal growth appeared. The growth was aseptically transferred on to prepared S.D.A plate and kept at room temperature. The fungal growth was identified as based on the physical and microscopic characteristics. About $50 \mathrm{~g}$ of rice husk was mixed with $500 \mathrm{ml}$ of distilled water in the ration of 1:10 to obtain homogenous slurry and then inoculated with $2 \mathrm{ml}$ of prepared Acremonium butyri solution and incubated at room temperature for up to 3 weeks with frequent shaking at certain intervals. Reducing sugar test was carried out to determine the reducing sugar released with UV-VIS spectrophotometer. The results obtained indicate that rice husk contained $32 \%, 30 \%, 29 \%$ and $8.4 \%$ of cellulose, hemicelluloses, extractives and lignin respectively. And a total of $0.936 \mathrm{~g} / \mathrm{l}$ of reducing sugar was released after 3 weeks of pre-treatment. The results implies that Acremonium butyri separated the component of rice husk (pre-treatment) as well as break down cellulose and hemicelluloses into its monomers (hydrolysis) thereby releasing sugar. Hence, Acremonium butyri is a good microorganism for biological pre-tretment and hydrolysis.

Keywords: Acremonium butyri, Rice Husk, Pre-treatment, Hydrolysis, Biofuel
\end{abstract}

\section{INTRODUCTION}

Demand for the sustainable energy has increased globally due to increasing population growth, depleting reservoirs of fossil fuels, and effects of climate change (Ben-iwo et al., 2016). Many countries have national desire to inculcate energy independence by creating alternative energy production (Anne, 2017). This therefore created interest in search of renewable sourced feedstock for the production of biofuels (Ezeoha et al., 2017). Biofuels refers to the fuels produced from renewable resources like energy crops, crop residues, forest and waste biomass (Mahapatra and Kumar, 2017). Some of these biofuels have been used for decades, like fuel wood, charcoal, ethanol, methanol, biodiesel, and biogas. Bioethanol and biodiesel are the most commonly used

UMYU Journal of Microbiology Research liquid biofuel in the transportation sector (Khamaiseh et al., 2014).

Biofuel production competes with food supply especially in developing economies. Lignocelluloses biomass such as agricultural residues, forest residues, industrial waste and municipal solid waste are the most cheaper alternatives that ensure food security (Mahapatra and Kumar, 2017). Lignocellulosic biomass consists of cellulose, hemicelluloses and lignin strongly bounded together and makes a complex structure that is difficult to breakdown and generates fermentable sugars (Zulkefflizan et al., 2017).

Pre-treatment during biofuel production is the solubilisation and separation of biomass cellulose, hemicelluloses and lignin for easy accessible to further chemical and biological treatments (Neves et al., 2007). 
UJMR, Volume 5 Number 2, December, 2020, pp 131 - 137 ISSN: 2616 - 0668

Pre-treatment of lignocellulosics aims to decrease crystallinity of cellulose, increase biomass surface area, remove hemicellulose, break the lignin barrier and expose the cellulose to hydrolytic enzymes that facilitate the conversion of carbohydrate polymers into fermentable sugars (Ezeoha et al., 2017). The process is physical, chemical and biological pretreatments. The physical process involved milling, grinding, chipping and extrusion in order to increase the accessible surface area, size of spores, and decrease the crystallinity of the biomass. The Chemical pre-treatment used concentrated or dilute of acid or alkali to increase internal surface area and porosity. Physico-chemical pretreatment is combination of both physical and chemical pretreatment with the aid of an alkali or acid such as steam explosion and ammonia fiber explosion process which can increase surface area and partial degradation of hemicellulose (Mohammad and Karimi 2008).

Most of the pre-treatments methods required expensive instruments and high energy. Moreover, wastes produced by chemicals can be hazardous to the human as well as the environment (Sun and Cheng 2002; Teymouri et al., 2004). Microorganisms and their enzymes offer pre-treatment method which is cheap, safe and environmentally friendly (Sun and Cheng 2002; Okano et al., 2005). In this process, microorganisms such as fungi are used to degrade lignin and hemicellulose in lignocellulosic biomass (Anwar et al., 2014).

Hydrolysis on the other hand breaks complex sugars in to their simpler unit thereby making cellulose readily accessible for the fermentation by microorganisms (Anwar et al., 2017). Enzymes hydrolysis is currently being employed due to the hazards posed by chemicals. Compared to acid hydrolysis, biological hydrolysis is more efficient with milder operating conditions, better sugar yields with and uses less chemicals input (Banerjee et al., 2010, Yang et al., 2011). Biological hydrolysis of pre-treated lignocellulosic materials involves enzymatic reactions that convert cellulose into glucose and hemicellulose into pentoses (xylose and arabinose) and hexoses (glucose, galactose, and mannose) (Yang, 2015).

Large numbers of microorganisms are capable of degrading cellulose (Ezenwanne, 2014). Bacteria belonging to Clostridium, Cellulomonas, Bacillus, Thermomonospora, Ruminococcus, Bacteriodes, Erwinia, Acetovibrio, Microbispora, and Streptomyces can produce cellulases enzymes (Bisaria, 1991). Cellulases producing bacteria Cellulomonas fimi and Thermomonospora fusca have been extensively studied (Duff and Murray, 1996).
Although anaerobes such as Clostridium thermocellum and Bacteroides cellulosolvens produce cellulases with high specific activity, their enzymes productivity is low (Duff and Murray, 1996). Anaerobes have very low growth rate and require anaerobic growth conditions, therefore most research for commercial cellulase production focused on fungi (Sun and Jiayang, 2001).

For fungi, members of the genera that have received considerable attention under aerobic conditions are Ahaetomium, and Helotium (Ascomycetes); coriolus, phanerochaete, poria, schizophyllum and serpula (Basidiomycetes); Aspergillus; Cladosporium, Fusarium, Geotrichum, myrothecium, paecilomyces, penicillium and trichoderma (Deuteromycetes) and Mucor (Zygomycetes). Neocallimastix, piromyces, caecomyce, orpimomyce and anaeromyces under anaerobic fungal division chytridiomycetes are considered to be the genera with prominent cellulolytic activity (Lynd et al., 2001). However, only a few of these microorganisms are known to produce significant quantities of cell-free enzymes capable of completely hydrolyzing crystalline in vitro (lyang, 2014). Fungal genera Trichoderma and Aspergillus are thought to be prominent cellulose producers where crude enzymes are produced in commercially quantity for agricultural usage (Bonelba and Ferrara, 2007; Rajesh et al., 2008). This research work aims at investigating the ability of Acremonium butyri (fungus) for pretreatment and hydrolysis of rice husk.

\section{MATERIALS AND METHODS \\ Collection of Samples}

Rice husks substrate was collected in a clean polythene bag from Kalambaina rice mills, Wamakko Local Government Area of Sokoto State. Dried roots of Piliostigma reticulatum (Kalgo) was obtained from traditional medicine seller in Sokoto Central Market which was used for the isolation of Acremonium butyri. All the samples were processed at the Microbiology Research laboratory in Usmanu Danfodiyo University Sokoto between.the dates of July, 2020 to September, 2020.

\section{Analysis of the composition of Rice Husks Extractives}

Soxhlet extractor was set-up as $2.5 \mathrm{~g}$ of rice husk was loaded into the cellulose thimble with $150 \mathrm{ml}$ acetone. Extraction was allowed to occur for $4 \mathrm{~h}$ with the residue being air dried at room temperature and later obtained constant weight in a convection oven at $105^{\circ} \mathrm{C}$. The $\%(w / w)$ of the extractives content was calculated using Eq. (1) (Blasi et al., 1991; Li et al., 2004; and Lin et al., 2010). 
UJMR, Volume 5 Number 2, December, 2020, pp 131 - 137 ISSN: 2616 - 0668

$\mathrm{W} 1$ (wt.\%) = Go - G1/Go x $100 \quad$... Equation 1

Where: W1 = Extractives,

Go = Dry weight of the sample,

$\mathrm{G} 1=$ Constant weight of the residues after extraction

\section{Hemicellulose}

From the extracted residue, 1g (G1) was transferred into a $250 \mathrm{ml}$ capacity Erlenmeyer flask and $150 \mathrm{ml}$ of $\mathrm{NaOH}\left(0.5 \mathrm{~mol} / \mathrm{dm}^{3}\right)$ was added. The mixture was heated for $3.5 \mathrm{~h}$ with distilled water after which the residue was filtered and washed until neutral $\mathrm{pH}$ was attained. The residue was then dried to a constant weight at $105^{\circ} \mathrm{C}$ in a convection oven (G2). Hemicellulose content (\%w/w) was calculated using the formula given in Eq. 2 (Ayeni et al., 2013; Blasi et al., 1991; Li et al., 2004; and Lin et al., 2010).

W2 (wt.\%) = G1 - G2/Go x $100 \quad$...... Equation 2

\section{Lignin}

From the extracted rice husk, 0.3g (G3) was weighed in a test tube and $3 \mathrm{ml}$ of $72 \% \mathrm{H}_{2} \mathrm{SO}_{4}$ was added. The mixture was allowed to stand for $2 \mathrm{~h}$ at room temperature with frequent shaking at 30 min interval after which, $84 \mathrm{ml}$ of distilled water was added (first step of hydrolysis). The second step of hydrolysis occurred in an autoclave for 1 hour at $121^{\circ} \mathrm{C}$. The mixture was filtered after it was cooled and constant weight of the residue was obtained using conventional oven (G4). Lignin content wt. \% was determined using Eq. 3 (Li et al., 2004; Sluiter et al., 2008).

W3 (wt.\%) $=$ G4(1-W1)/G3 x 100

\section{Cellulose}

The cellulose content (wt.\%) was calculated by difference from extractives, hemicellulose, lignin (Blasi et al., 1991; Li et al., 2004; and Lin et al., 2010).

$\mathrm{W} 4(\mathrm{wt} . \%)=100-(\mathrm{W} 1+\mathrm{W} 2+\mathrm{W} 3) \ldots$ Equation 4

\section{Preparation of Media}

All media used in this research work was prepared according to the manufacturer's instructions. Sabouraud Dextrose Agar (SDA) was prepared by suspending $65 \mathrm{~g}$ of the medium in $1 \mathrm{~L}$ of distilled water, dissolved by heating with frequent agitation and autoclaved at $121^{\circ}$ C for 15 minutes (Oyeleke and Manga, 2008).

Isolation and Inoculums Preparation of Acremonium butyri

For isolation of Acremonium butyri, sample of dried roots of Piliostigma reticulatum (Kalgo) were washed and kept under moist environment until fungal growth appeared. The growth was transferred onto a plate of SDA and kept at room temperature for a period of 7 days. The growth was observed daily for physical and macroscopic characterizations. The growth was later identified microscopically and maintained in slant bottle of SDA (Adesina and Onilude, 2013). Inoculums was prepared by adding $15 \mathrm{ml}$ of sterile distilled water in to 5day-old growth on slant bottle of SDA and scraped aseptically with inoculating loop. Aliquot $(2 \mathrm{ml})$ of the suspension was used as inoculums for (Negi and Banerjee, 2006).

Pre-treatment-hydrolysis of Rice Husk

About $50 \mathrm{~g}$ rice husk was mixed with $500 \mathrm{ml}$ of distilled water in the ratio $1: 10$ to obtain homogenous slurry and then inoculated with $2 \mathrm{ml}$ of Acremonium butyri and incubated at room temperature for up to 3 weeks with frequent shaking at certain intervals. After 3 weeks, the slurry was autoclaved at $121^{\circ} \mathrm{C}$ for $15 \mathrm{~min}$. It was then filtered using Whatman filter paper No1 and filtrate was further analysed for content of reducing sugar (Wang et al., 2010).

\section{Determination of Reducing Sugar}

The reducing sugar content was determined using the dinitrosalicylic acid (DNS) colorimetric method as used by Rabah et al, (2011) with glucose as standard. It was assayed by adding 2 $\mathrm{ml}$ of 3,5 -DNS reagents to $1 \mathrm{ml}$ of the filtrate and the mixture was heated in a heater bath for $10 \mathrm{~min}$ to develop a red-brown colour. Then $1 \mathrm{ml}$ of $40 \%$ potassium sodium tartrate solutions was added to stabilize the colour, it was then cooled to room temperature. The absorbance of the sample was measured at $540 \mathrm{~nm}$ using ultraviolet (UV-VIS) spectrophotometer. The reducing sugar content was determined using Eq. 5 (Rabah et al., 2011).

\%Reducing sugar $(\mathrm{mg} / \mathrm{dl})=$ Abs. of sample/Abs. of Std x Conc. of Std............ Equation 5

Keys: Abs. = Absorbance, Std. = Standard, Conc. $=$ Concentration

\section{RESULTS}

\section{Structural Compositions of the Rice Husk}

Structural compositions of rice husk were investigated to determine the extractives, hemicellulose, lignin and cellulose. Fig. 1 shows the results of structural compositions of rice husk presented in mean and standard deviation. 
UJMR, Volume 5 Number 2, December, 2020, pp 131 - 137 ISSN: 2616 - 0668

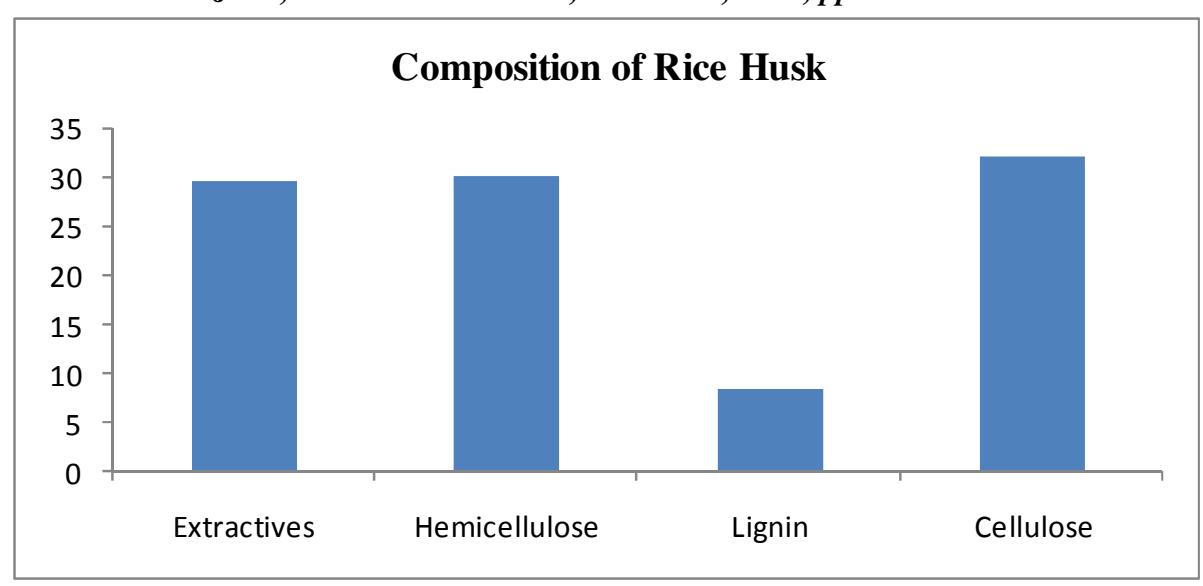

Fig. 1: Mean structural compositions of rice husk

Reducing sugar released after hydrolysis using Acremonium butyri

A total of $0.936 \mathrm{~g} / \mathrm{l}$ of reducing sugar was determined after 3 weeks of pre-treatment-hydrolysis of rice husks with Acremonium butyric as present in the table below:

\begin{tabular}{|c|c|c|c|c|c|}
\hline Test organism & $\begin{array}{l}\text { Time of } \\
\text { hydrolysis }\end{array}$ & pre-treatment & $\begin{array}{l}\text { Amount of } \\
\text { produce }\end{array}$ & reducing & sugar \\
\hline Acremonium butyri & 3 weeks & & $0.936 \mathrm{~g} / \mathrm{l}$ & & \\
\hline
\end{tabular}

\section{DISCUSSION}

The result of the structural composition of rice husk shows a high proportion of cellulose and hemicellulose accounting for about $32 \%$ and $30 \%$, respectively. The lignin content found was $8.4 \%$. This might be attributed to the fact that rice is herbaceous plant known to have less rigid cell wall as such is expected to have more cellulose content. Sticlen, (2007) reported that lignocellulosic biomass contains about $30 \%$ to $50 \%$ cellulose, for which rice husk is characterized as one of the lignocellulosic biomass. This is similar with the studies by Noha, (2015) who reported a cellulose content of $31.01 \%, 32.23 \%, 30.80 \%$ and $33.65 \%$ from rice straw collected from Egypt, Murcia, Valencia and Andalusia respectively. The study also showed similarity with finding of Anwar et al. (2017) who reported a cellulose content of rice husk of $32.67 \%$ in their study. The result of hemicelluloses of this research falls within the range of $5 \%$ to $30 \%$ for lignocellulosic biomass (Jie, 2004). The result of this work differs from the values of $26.47 \%, 25.26 \%, 24.79 \%$ and $26.68 \%$ previously reported for rice straw collected from Egypt, Murcia, Valencia and Andalusia, respectively (Noha, 2015). However, the study shows similar finding of Williams and Nugranad (2000), who reported a hemicelluloses content of $29.3 \%$ from rice husk in their work. When compared with the hemicelluloses content of $11.96 \%$ and $17.7 \%$ reported by Saha et al. (2005) and Park et al. (2004) respectively. The content revealed higher value, which might be as a result of difference in geographic location, methods of harvesting or processing methods. Lignin content of this research is lower than the value of $18.81 \%$ reported by Anwar et al. (2004) whose research was conducted using rice husk in Indonesia. Moreover, another study on rice husk by Noha, (2015) in Egypt showed higher content of lignin compared the value found in this work. The finding implies that rice husk contained substantial sugar that can be converted to product such as alcohols or biofuels.

Extractives account for about $29.6 \%$ and are mainly a group of cell wall chemicals comprising fats, fatty acids, phenols and many other organic compounds. Extractives are nonstructural components of plant cell walls responsible for colour, smell and durability (Rowell, 2012). The value of extractives in this work is higher compared to the value (11\%) reported by Adila et al. (2019) from Pineapple leaves. The results is also higher than the values found in sugar cane bagasse and Shea tree sawdust reported by Ayeni et al. (2015) which account for $2.14 \%$ and $1.9 \%$, respectively. The differences in the values of extractives might be attributed to the difference in the biomass substrates.

Reducing sugar was determined after 3 weeks of hydrolysis to ascertain the ability of Acremonium butyri to produce cellulases that hydrolyze cellulose and release sugar. The amount (average) of reducing sugar released was $0.936 \mathrm{~g} / \mathrm{l}$. The result showed high content of reducing sugar when compared with standard glucose $(1 \mathrm{~g} / \mathrm{l})$. 
UJMR, Volume 5 Number 2, December, 2020, pp 131 - 137 ISSN: 2616 - 0668

The result is similar with $0.937 \mathrm{ml} / \mathrm{ml}$ reported as the maximum sugar released using Aspergillus niger at day eight (Stephen et al., 2018). Oyeleke et al. (2010) reported 1.82 $\mathrm{ml} / \mathrm{ml}$ of reducing sugar using Bacillus megaterium which is higher than the amount obtained in my research work. Another study by Abdullahi et al, (2017) revealed lower amount $(0.06 \mathrm{~g} / \mathrm{l})$ of reducing sugar when rice husk was hydrolyzed with dilute $\mathrm{HCl}$. This implies that Acremonium butyri was able to partake in the

\section{REFERENCES}

Abdullahi, A. A., Aliero, B. L., Aliero, A. A., Zuru, A.A and Rabah, A. B. (2017). Optimization of Ethanol Production from Switchgrass (Panicum virgatum L.) Grown in Sokoto Geoecological Zone of Nigeria. International Journal of Chemistry, Pharmacy and Technology, 2(1), 43-56.

Adesina, F. C and Onilude A. A (2013). Isolation, identification and screening of xylanase and glucanase-producing microfungi from degrading wood in Nigeria. African Journal of Agricultural Research. 8 (34), pp. 4414-4421

Adila, M. M., Jeng, S. L., Nasir, S. A., Hashim, $H$. and Shin, W. H (2019) Characteristics of Cellulose, Hemicellulose and Lignin of MD2 Pineapple Biomass. Journal of Chemical Engineering Transactions, 72. 79-82

Anne, K. (2017). Development of pretreatment technology and enzymatic hydrolysis for biorefineries. Doctoral dissertation for the degree of Doctor of Science in Technology to be presented with due permission of the School of Chemical Technology for public examination and debate in Auditorium V1 in Material technology building, at Aalto University School of Chemical Technology. Unpublished.

Anwar, M., Bambang, P and Nita, A (2017). Lignin Isolation Process from Rice Husk by Alkaline Hydrogen Peroxide: Lignin and Silica Extracted. AIP Conference Proceedings 1823, 020013.

Anwar, Z., Gulfraz, M. and Irshad, M (2014) Agro-industrial Lignocellulosic biomass a Key to Unlock the Future Bioenergy: A Brief Review. Journal of Radiation Research and Applied Sciences 7(2), 163-173.

Ayeni A. O., Hymore F. K., Mudliar S. N., Deskmukh S. C., Satpute D. B., Omoleye J. A. and Pandey R. A. (2013). Hydrogen peroxide and lime based oxidative pretreatment of wood waste to enhance enzymatic hydrolysis for a

UMYU Journal of Microbiology Research pretreatment of rice husk as well as hydrolysis; hence Acremonium butyri is a good hydrolytic organism.

\section{CONCLUSION}

Acremonium butyri was found to pre-treat and hydrolyzed rice husk. This research showed that Acremonium butyri produced cellulose and amylase that can hydrolyze agricultural waste to release glucose for the production of biofuels.

biorefinery: process parameters optimization using response surface methodology. Journal of Fuel, 106, 187-194.

Ayeni, A. O., Adeeyo, O. A., Oyinlola, M. O. and Temitayo E. 0 (2015) Compositional Analysis of Lignocellulosic Materials: Evaluation of an Economically Viable Method Suitable for Woody and Non-Woody Biomass. American Journal of Engineering Research, 4(4). 14-19

Banerjee, S., Mudliar, S., Sen, R., Giri, B., Satpute, D., Chakrabarti, T., and Pandey, R.A. (2010). Commercializing Lignocellulosic Bioethanol: Technology Bottlenecks and Possible Remedies. Biofuels Bioproducts and Biorefining. 4, 77-93.

Ben-iwo, J., Manovic, V., and Longhurst, P. (2016). Biomass resources and biofuels potential for the production of transportation fuels in Nigeria. Renewable and Sustainable Energy Reviews, 63, 172-192. https://doi.org/10.1016/j.rser.2016.05 .050

Bisaria, V.S. (1991). Bioprocessing of Agroresidues to glucose and chemicals in Bioconversion of Waste Materials to Industrial Products. Martin, A.M. (Ed.), Elsevier, London, Pp. 210-213.

Blasi C. D., Signorelli G., Di Russo C., and Rea G. (1991). Product distribution from pyrolysis of wood and agricultural residues, Industrial Engineering Chemistry Research, 38(6), 2216-2224.

Bonelba, P. and Ferrara, M. (2007). Bioethanol via enzymatic Hydrolysis of Cellulosic Biomass. Accessed from http: / /www.foa.org/biotech/seminaro ct2007.html

Duff, S. J. B. and Murray, W. D., (1996). Bioconversion of Forest Products Industry Waste Cellulosics to Fuel Ethanol: a review. Journal of Bioresource Technology. 55, 1-33. 
UJMR, Volume 5 Number 2, December, 2020, pp 131 - 137 ISSN: 2616 - 0668

Ezeoha1, S. L., Anyanwu, C. N. and Nwakaire, J. N. (2017). The Prospects, Impacts, and Research Challenges of Enhanced Cellulosic Ethanol Production: A Review. Nigerian Journal of Technology 36(1), 267-275.

Ezenwanne, V. C. (2014). Fermentation Products of Rice Husks, by Bacteria and Fungi Isolates from Rice Husk Dump Site. A dissertation submitted to University of Nigeria Nsukka in partial fulfillment of the Requirements for the award of degree of master of Science (m.sc.) In industrial biochemistry. Pp 17-25. Not punlished

lyang, E. J. (2014) Evaluation of Pre-treatmemt Methods for Enzymatic Saccarification of Alstonia boonei Wood Sawdust and Fermentation Using Saccharomyses cereviciae and Zymomonas mobilis for Ethyl Alcohol Production. Masters Dissertation Submitted to University of Nigeria Nsukka. Not Published.

Jie, D. M. S. (2014). Butanol Production from Lignocellulosic Biomass and Agriculture Residues by Acetone-Butanol-Ethanol Fermentation. A Dissertation Presented in Partial Fulfillment of the Requirements for the Degree, Doctor of Philosophy in the Graduate School of the Ohio State University. 210-255. Unpublished.

Khamaiseh, E. I., Hamid, A. A., Abdeshahian, P., Mohtar, W., Yusoff, W., and Kalil, M. S. (2014). Enhanced Butanol Production by Clostridium acetobutylicum NCIMB 13357 Grown on Date Fruit as Carbon Source in P2 Medium. The Scientific World Journa. Hindawi Publishing Corporation. http://dx.doi.org/10.1155/2014/39575 4

Li, S., Xu S., Liu S., Yang C and Lu Q (2004). Fast pyrolysis of biomass in free-fall reactor for hydrogen-rich gas. Journal of Fuel Process Technology, 85(8-10), 1201-1211.

Lin L., Yan R., Liu Y and Jiang W. (2010). Indepth investigation of enzymatic hydrolysis of biomass wastes based on three major components: cellulose, hemicellulose, and lignin, Bioresource Technology, 101 (21), 8217-8223.

Lynd, L., Weimer, P., Van, W., Pretorius, l., (2001). Micobial Cellulose Utilization: Fundamentals and Biotechnology. Journal of Microbology and Moleculer Biology 66:506-577

Mahapatra, M. K., and Kumar, A. (2017). A Short Review on Biobutanol , a Second Generation Biofuel Production from

UMYU Journal of Microbiology Research
Lignocellulosic Biomass, Journal of Clean Energy Technologies. 5(1), 27-30. https://doi.org/10.18178/jocet.2017.5. 1.338

Miller G. L (1959). Use of dinitrosalicylic acid reagent for determination of reducing. Journal of Analytical Chemistry. 31: 426

Negi, S. and Banerjee, R. (2006). Optimization of Amylase and Protease Production from Aspergillus awamori in Single Bioreactor Through EVOP Factorial Design Technique. Journal of Food Technology and Biotechnology. 44 (2), 257-261.

Neves, M. A., Kimura, T., Shimizu, N. and Nakajima, M. (2007). State of the art and future trends of bioethanol production. Dynamic Biochemistry, Process Biotechnology and Molecular Biology 1 (1), 1-14.

Noha, S. E. (2015). Utilization of Energy from Residual Biomass of Rice Husk in Egypt. A Doctoral Thesis Submitted to university of Granada. Unpublished.

Okano, K., Kitagawa, M., Sasaki, Y. and Watanabe, T. (2005). Conversion of Japanese Red Cedar (Cryptomeria japonica) into a Feed for Ruminants by White-Rot Basidiomycetes. Journal of Animal Feed Science Technology, 120: 235-243.

Oyeleke, S. B. and Manga, S. B. (2008). Essentials of Laboratory Practical in Microbiology. First Edition, Tolbest Publishers, Minna, Nigeria. 36-67.

Oyeleke, S. B., Shnada, H. A. and Egwim, E. (2010). Production and Characterization of Amylase produced by Bacillus megaterium Isolated from a Local Yam Peels Dumpsite in Minna, Niger State. Journal of Microbiology and Antimicrobials 2(7), 88-92.

Park, E.Y., Anah, P. N. and Okuda, N. (2004). Bioconversion of waste office paper to $\mathrm{L}(+)$-lactic acid by the filamentous fungus Rhizopus oryzae, Journal of Bioresource Technology.

Rabah, A. B., Oyeleke, S. B., Manga, S. B. and Hassan, L. G. (2011). Utilization of millet and guinea corn husks for Bioethanol production. African Journal Microbiological Resource; 5(31): 57215724.

Rajesh, A., Rajesh, E., Rajendran, R., and Jeyachandrans, N., (2008). Production of Bioethanol from Cellulosic Cotton Waste through Microbial Extracellular Enzymatic Hydrolysis and Fermentation. Electronic Journal of Environment www.ujmr.umyu.edu.ng 
UJMR, Volume 5 Number 2, December, 2020, pp 131 - 137 ISSN: 2616 - 0668

Agricultural and Food Chemistry. 7(6); 2984-2994.

Rowell, R. M. ( 2012) Handbook of wood chemistry and wood composites, CRC press, Boca Raton, Florida, USA.

Saha, B. C., Iten, L. B., Cotta, M. A. and Wu, Y. V. (2005). Dilute Acid Pretreatment, Enzymatic Saccharification and Fermentation of Wheat Straw to Ethanol. Journal of Process Biochemistry 40: 3693-3700.

Sluiter, A., Hames, B., Ruiz, R., Scarlata, C., Sluiter, J., Templeton, D. and Crocker, D. (2008). Determination of Structural Carbohydrates and Lignin in Biomass, Colorado, Laboratory. Analytical Procedure.

Sticlen, M. B. (2007). Feedstock Crop Genetic Engineering for Alcohol fuels. Journal of Crop Science. 47: 2238-2248.

Sun, Y., Cheng, J. (2002). Hydrolysis of Lignocellulosic Materials for Ethanol Production: A Review. Journal of Bioresouce and Technology 83, 1-11.

Sun, Y. and Jiayang, C. (2001). Hydrolysis of Lignocellulosic Materials for Ethanol production: A Review. Journal of Bioresource Technology 83 1-11

Teymouri, F., Laureano-Pérez, I., Alizadeh, H. and Dale, B. E. (2004). Ammonia Fiber
Explosion Treatment of Corn

Stover. Applied Biochemistry and Biotechnology 115(1-3): 951-963.

Wang, A., Wang, Y., Jiang, T., Li, L., Ma, C., and $\mathrm{Xu}, \mathrm{P}$. (2010). Production of 2,3butanediol from corncob molasses, a waste by-product in xylitol production. Journal of Applied Microbiology and Biotechnology, 87(3): 965-970. DOI: $10.1007 / \mathrm{s} 00253-010-2557-8$

Williams, P. T. and Nugranad, N. (2000). Comparison of products from the pyrolysis and catalytic pyrolysis of rice husks. Journal of Energy. 25:493-513.

Yang, B., Dai, Z. Y., Ding, S. Y., and Wyman, C. E. (2011). Enzymatic Hydrolysis of Cellulosic Biomass. Biofuels 2(4), 421450.

Yang, M. (2015). The use of lignocellulosic biomass for fermentative butanol production in biorefining processes. Dissertationes Forestales 202, 49. Available http: / /dx.doi.org/10.14214/df.202.

Zulkefflizan, J., Madihah, M. S. and Adibah, Y. (2017). Potential Use of Lignobiomass for Sugar Production. Journal of Applied Biotechnology and Bioengineering. 3 (6). 